J. Dairy Sci. 97:2145-2154

http://dx.doi.org/10.3168/jds.2013-7163

(C) American Dairy Science Association ${ }^{\circledR}$, 2014. Open access under CC BY-NC-ND license.

\title{
A field study to determine the prevalence, dairy herd management systems, and fresh cow clinical conditions associated with ketosis in western European dairy herds
}

\author{
Anna C. Berge ${ }^{\star 1}$ and Geert Vertenten† \\ *Department of Reproduction, Obstetrics and Herd Health, Faculty of Veterinary Medicine, Ghent University, Salisburylaan 133,9820 Merelbeke, \\ Belgium \\ †Elanco Animal Health, Plantin en Moretuslei 1A, 2018 Antwerp, Belgium
}

\begin{abstract}
The aim of this study was to determine the prevalence, major management systems, and fresh cow clinical conditions associated with ketosis in western European dairy herds. A total of 131 dairies were enrolled in Germany, France, Italy, the Netherlands, and the United Kingdom during 2011 to 2012. A milk-based test for ketones (Keto-Test; Sanwa Kagaku Kenkyusho Co. Ltd., Nagoya, Japan; distributed by Elanco Animal Health, Antwerp, Belgium) was used for screening cows between d 7 and 21 after calving and ketosis was defined as a Keto-Test $\geq 100 \mu \mathrm{mol} / \mathrm{L}$. Study cows were observed for clinical disease up to $35 \mathrm{~d}$ postcalving. Multivariate analysis (generalized estimating equation logistic regression) was performed to determine country, farm, management, feed, and cow factors associated with ketosis and to determine associations between ketosis and fresh cow diseases. Thirty-nine percent of the cows were classified as having ketosis. The herd average of ketosis was $43 \%$ in Germany, $53 \%$ in France, $31 \%$ in Italy, $46 \%$ in the Netherlands, and $31 \%$ in the United Kingdom. Of the 131 farms, $112(85 \%)$ had $25 \%$ or more of their fresh cows resulting as positive for ketosis. Clinical ketosis was not reported in most farms and the highest level of clinical ketosis reported was $23 \%$. The risks of ketosis were significantly lower in Italy and the United Kingdom compared with France, the Netherlands, and Germany. Larger herd size was associated with a decreased risk of ketosis. The farms that fed partially mixed rations had 1.5 times higher odds of ketosis than those that fed total mixed rations. Cows that calved in April to June had the highest odds of ketosis, with about twice as high odds compared with cows that calved in July to September. The cows that calved in January to March tended to have 1.5 times higher risk of ketosis compared with cows that calved
\end{abstract}

Received June 20, 2013.

Accepted November 11, 2013

${ }^{1}$ Corresponding author: anna.berge@ugent.be in July to September. The odds of ketosis in parity 2 and parity 3 to 7 was significantly higher (1.5 and 2.8 times higher, respectively) than the odds of ketosis in parity 1 . The odds of ketosis was significantly smaller in parity 2 compared with parity 3 to 7 . Ketosis was associated with significantly higher odds of all common fresh cow conditions: metritis, mastitis, displaced abomasum, clinical ketosis, lameness, and gastrointestinal disorders. Odds of ketosis in cows having had twins or dystocia were not increased, whereas higher odds of ketosis were observed in cows with milk fever or retained placenta.

Key words: ketosis, postpartum disease, prevalence, milk ketone

\section{INTRODUCTION}

Ketosis in dairy cows, also referred to as subclinical ketosis was described already in the 1950s (Holmes, 1950). It has become a very common metabolic disorder in modern dairy production as productivity increases (Andersson, 1988; Duffield, 2000). Ketosis has an economic impact on the herd, involving decreased milk production, increased incidence and duration of fresh cow diseases, increased time to conception, and an increased risk of culling (McLaren et al., 2006; Ospina et al., 2010a; Chapinal et al., 2012; Dubuc et al., 2012; Roberts et al., 2012). Extreme cases of acute clinical ketosis are routinely recognized and diagnosed in cows by farmers and veterinarians in the periparturient period. The observed clinical signs for these cases may include extreme loss of body condition, nervous signs, and decreased feed intake and milk yield (Baird, 1982). However, the signs of ketosis are often subtle and missed by farmers; subsequently, the true incidence of ketosis may be underdiagnosed.

Ketosis can be diagnosed by measuring ketone bodies present in blood, urine, or milk. The Keto-Test (Ketolac test strip; Sanwa Kagaku Kenkyusho Co. Ltd., Nagoya, Japan; distributed by Elanco Animal Health, Antwerp, Belgium) is a cowside milk test to semiquantitatively 
measure BHBA in the milk and can be used for screening cows for ketosis (Geishauser et al., 1998, 2000). When using milk at a cutoff point of $100 \mu \mathrm{mol} / \mathrm{L}$ (corresponding to a serum range of 1,000 to $1,400 \mu \mathrm{mol} / \mathrm{L}$ ), the sensitivity of the test has been estimated at $83 \%$ and the specificity at $82 \%$ (Oetzel, 2004).

The prevalence of ketosis in European Union dairy cows and in the most common management systems in the postcalving transition period has, until recently, been largely unexplored, with reports indicating that it is highly prevalent and entails high production costs (McKay, 2012). A recent study in May 2011 to October 2012 in 10 European countries indicated that the prevalence of ketosis, defined as serum BHBA concentration $\geq 1,200$ to $1,400 \mu \mathrm{mol} / \mathrm{L}$ in cows within 2 to $15 \mathrm{DIM}$ was $21.8 \%$, ranging from 11.2 to $36.6 \%$ (Suthar et al., 2013). The aim of this field study was to determine the prevalence, major management systems, and fresh cow clinical conditions associated with ketosis in western European dairy herds.

\section{MATERIALS AND METHODS}

This study was a longitudinal survey including 4,709 fresh cows in 131 herds in 5 European countries tested between July 2011 and October 2012. The farms were a convenience sample selected by participating veterinarians from 39 veterinary practice districts in Germany, France, the Netherlands, Italy, and the United Kingdom. The farms selected were considered as normal herds (i.e., with no bias toward herds at risk from ketosis and with no routine ketosis prevention addi- tive being used in the herd). All calving cows in the selected herds were included and enrolled for a period of 1 to 2 mo, depending on calving rate and herd size, with the aim of having at least 12 cows with complete information per farm (Oetzel, 2003). The minimum herd size for enrollment was set at 60 cows to achieve the minimum number of cows within the sampling time frame of the study.

Farm information included name and address of dairy, lactating herd size, average yearly milk production, and breed. Information on management, housing, and feeding systems was also collected. The cow information included test date, calving date, parity, and 1 ketosis milk testing at $\mathrm{d} 7$ to 21 postcalving, with observations for clinical disease performed by the farm staff at $\mathrm{d} 0$ to 35 postcalving. Disease diagnosis was according to clinical symptoms and definitions that were provided to the farmer and the participating veterinarians on each study farm. The disease conditions were classified as abortion, dystocia, twins, retained placenta (RP), milk fever, metritis, mastitis, clinical ketosis, displaced abomasum (DA), lameness, gastrointestinal disorder, or any other condition (Table 1). Milk from cows showing clinical disease tested for ketosis on the day of diagnosis of the condition.

A milk BHBA test strip (Keto-Test) was used by the participating veterinarians for screening a milk sample from cows. The strip was dipped into the milk sample for $3 \mathrm{~s}$, read after $1 \mathrm{~min}$, and recorded according to the color scale provided with the test. The color scale shows 6 colors corresponding to nominal levels of 0,50 , 100, 200, 500, and 1,000 $\mu \mathrm{mol}$ of BHBA/L of milk. A

Table 1. Clinical disease definitions in a study of ketosis in European dairy cows

\begin{tabular}{|c|c|}
\hline Diagnosis & Definition \\
\hline Twins & Production of more than 1 calf \\
\hline Dystocia & Assistance with parturition due to difficulties with calving \\
\hline Abortion & Birth of a calf before $270 \mathrm{~d}$ of gestation \\
\hline Retained placenta & Placenta present more than $24 \mathrm{~h}$ after calving \\
\hline Milk fever & $\begin{array}{l}\text { Cow requires treatment with calcium by subcutaneous or intravenous injection due to clinical signs of milk } \\
\text { fever, including down and unable to rise; muscular weakness, including S-bend in neck; cold extremities; dry } \\
\text { nose; or constipation. (Cow is not regarded as having milk fever if a calcium treatment is given only because } \\
\text { of age or other risk factor, or as a preventive.) }\end{array}$ \\
\hline Metritis & Purulent and smelly uterine discharge with temperature $\geq 39.5^{\circ} \mathrm{C}\left(103.5^{\circ} \mathrm{F}\right)$ \\
\hline Mastitis & Change in the appearance of the milk or udder indicative of infection \\
\hline Displaced abomasum & $\begin{array}{l}\text { Presence of a gas-filled abomasum on the left or upper right flank, giving a characteristic "ping" sound on } \\
\text { percussion or splashing on ballottement }\end{array}$ \\
\hline Lameness & $\begin{array}{l}\text { Locomotion score of } 2 \text { or more (scale of } 0-3) \text {; cow is noticeably lame on } 1 \text { or more limbs, and the affected } \\
\operatorname{leg}(\mathrm{s}) \text { can be identified }\end{array}$ \\
\hline Gastrointestinal disorder & $\begin{array}{l}\text { Change in fecal consistency from that typical for herd, or individual, possibly combined with changed rumen } \\
\text { activity (reduced cudding an abnormal rumen activity) }\end{array}$ \\
\hline Clinical ketosis & $\begin{array}{l}\text { Decrease in milk yield (perceived or recorded milk yield decrease } \geq 10 \% \text { with no signs of estrus; udder not } \\
\text { full before milking), reduced feed intake and (or) appetite (cow not feeding vigorously, standing back from } \\
\text { feed trough; decrease/refusal in concentrate intake), low rumen fill, reduced activity or demeanor (dullness, } \\
\text { listlessness), excessive loss of body condition (loss of BCS compared with immediate postcalving BCS of } 1 \\
\text { unit or more; dull coat, indicative of weight loss), constipation/reduced fecal output or hard/dry feces, ketone } \\
\text { odor in breath/milk, nervous signs (weakness, mania, apparent blindness, pica) }\end{array}$ \\
\hline
\end{tabular}


recording of $100 \mu \mathrm{mol}$ of $\mathrm{BHBA} / \mathrm{L}$ of milk or higher was defined as ketosis.

All data from the original data-capture written forms were entered into a Microsoft Excel spreadsheet (Microsoft Corp., Redmond, WA) by A. C. Berge. The individual cow was the observational unit. Cows were retained that had complete data regarding test and calving date, parity, and Keto-Test results. A cow was defined as positive for ketosis if she had a milk KetoTest of $100 \mu \mathrm{mol}$ of BHBA/L or higher. The cow parity was categorized as parity 1 , parity 2 , parity 3 to 7 , and parity 8 or higher. The number of DIM was calculated as test day minus calving date. Housing systems were categorized as cubicles, cubicles and yards, straw yards, tie-up, or other (grazing). Management systems were categorized as "indoor all year," "summer at pasture," or "outdoor alternative." Feeding systems were categorized as TMR, partial mixed ration (PMR), or forage and concentrate separate. The calving time was categorized into yearly quarters: January to March (quarter 1), April to June (quarter 2), July to September (quarter 3), and October to December (quarter 4). Dairy herd breeds were categorized as Holstein-Friesian, Holstein-Friesian mixed with other breeds, German Black Pied, and others. Stratified analysis was used to initially describe the data and determine categorical variables. The prevalence of ketosis on a country basis, farm basis, and in relation to different predictive variables was determined.

A general linear model was used to evaluate differences in within-herd prevalence of ketosis between countries. A logistic regression model with a generalized estimating equation (GEE) was used to determine herd-level factors associated with ketosis while controlling for clustering of farms within a country (Agresti, 2002a,b). A repeated measure on farm nested within country was included with an unstructured covariance matrix. Herd-level factors tested for inclusion using a manual backward selection procedure ( $P$-value for retention $\leq 0.10$ ) were continuous variables: lactating herd size and milk production average and categorical variables: herd veterinarian performing the KetoTest, breed, housing system, management system, and feeding system, using a backward stepwise selection procedure. Cow-level factors tested for inclusion were parity (categorized as parity 1, parity 2, parity 3 to 7 , and parity 8 to 12), number of DIM (continuous), and calving quarter (categorical). Interactions between variables were tested and retained in the model if $P$-value for retention $\leq 0.10$. Correlations between independent variables were evaluated using a limit of 0.6 for the correlation coefficient $(P \leq 0.05)$, indicating highly correlated variables, where the most biologically plausible would be chosen. The exponentiated estimates were calculated to give an odds ratio for the relationships. Variables were considered statistically significant at $P$ $\leq 0.05$ and $P$-values between 0.05 and 0.10 were referred to as nonsignificant trends.

Relationships between ketosis in the study screening (d 7-21 postpartum) and clinical disease within d 35 postpartum were statistically analyzed using separate clinical disease-specific GEE logistic regression models controlling for clustering of cows within farms and countries. The models did not determine temporal relationships, as the date of diagnosis had not been recorded on many farms; it was simply indicated that the cow had a disease in the 35-d monitoring period. For clinical conditions recorded before the Keto-Test sample: dystocia, twins, RP, and milk fever, the predictive variable was the clinical condition and the outcome dependent variable was ketosis. For clinical conditions recorded after the Keto-Test sample: metritis, mastitis, clinical ketosis, DA, lameness, and gastrointestinal disorder, the predictive variable was ketosis at screening and the outcome variable was the clinical condition. Other covariates tested for inclusion in the models were parity, calving quarter, DIM, and interaction effects as described above. Of the 4,709 cows enrolled in the study, 440 cows were tested at the time of diagnosis of clinical disease and the results were summarized.

\section{RESULTS}

This study included 4,709 fresh cows in 131 herds tested between July 2011 and October 4, 2012 (Table 2 ). The study cows were $30 \%$ heifers, $28 \%$ in parity 2 , $41 \%$ in parity 3 to 7 , and the remaining $0.7 \%$ in parity 8 or higher. The cows were tested between d 7 and 21 after calving and the average time for testing was 13 DIM. For the 4,709 cows, the Keto-Test results were as follows: $31.5 \%$ scored $0,29.3 \%$ scored $50,25.5 \%$ scored $100,9.8 \%$ scored $200,3.3 \%$ scored 500 , and $0.6 \%$ scored 1,000 (Table 3). Thirty-nine percent of the cows were classified as having ketosis (Table 3). The herd average of ketosis was $43 \%$ in Germany, $52 \%$ in France, $31 \%$ in Italy, $46 \%$ in the Netherlands, and $31 \%$ in the United Kingdom (Table 2). Of the 131 farms, 112 (85\%) had $25 \%$ or more of their fresh cows screened positive for ketosis. Clinical ketosis was not reported in most farms, the average herd prevalence was $1.6 \%$, and the highest level of clinical ketosis reported was $23 \%$. Cows that were fed forage and concentrate separately had the lowest prevalence of ketosis (33\%), followed by those on a TMR (36\%), and cows fed PMR had 50\% ketosis (Table 4). The prevalence of ketosis was lowest in systems with combined cubicles and straw yards or tie-up barns, 39\% in systems with cubicles, and $54 \%$ in straw yards (Table 4). The prevalence of ketosis in cows housed indoors all 
Table 2. Herds enrolled in a study of ketosis in European dairy cows with herd factors and herd-level prevalence of clinical ketosis and ketosis ${ }^{1,2}$

\begin{tabular}{|c|c|c|c|c|c|c|c|c|}
\hline Item & $\begin{array}{l}\text { No. of } \\
\text { herds }\end{array}$ & \multicolumn{4}{|c|}{ Herd factor } & $\begin{array}{c}\text { Herd-level } \\
\text { ketosis } \\
(\% ; \text { LSM })\end{array}$ & \multicolumn{2}{|c|}{$95 \%$ CI $(\%)$} \\
\hline $\mathrm{DE}$ & 31 & $462(96)$ & $2.5(0.1)$ & $13.8(0.3)$ & $3.5(1.0)$ & $43^{\mathrm{b}}$ & 35 & 50 \\
\hline FR & 24 & $121(17)$ & $2.4(0.1)$ & $13.7(0.3)$ & $0.3(0.3)$ & $52^{\mathrm{b}}$ & 44 & 62 \\
\hline IT & 26 & $333(50)$ & $2.4(0.1)$ & $12.4(0.5)$ & $2.4(0.7)$ & $31^{\mathrm{a}}$ & 23 & 39 \\
\hline All herds & 131 & $294(28)$ & $2.6(0.1)$ & $13.5(0.2)$ & $1.6(0.3)$ & 41 & & \\
\hline
\end{tabular}

${ }^{\mathrm{a}, \mathrm{b}}$ Herd-level ketosis values in countries with different superscript letters are significantly different $(P<0.05)$.

${ }^{1}$ Results of herd factors are given as mean and SE (in parentheses).

${ }^{2}$ Least squares means and $95 \%$ confidence limits from general linear model $\left(F\right.$-value $\left.=5.00 ; \mathrm{df}=4 ; P<0.01 ; \mathrm{R}^{2}=0.14\right)$.

${ }^{3} \mathrm{DE}=$ Germany $; \mathrm{FR}=$ France IT $=$ Italy; $\mathrm{NL}=$ the Netherlands; UK = United Kingdom.

year was $35 \%$; cows that were at pasture in the summer or other outdoor alternative housing system had, on average, 44 to $46 \%$ ketosis (Table 4 ).

The GEE logistic regression model estimating odds of ketosis indicated that the herd-level factors significantly associated with ketosis were lactating herd size and feeding system, with cow-level factors including parity and calving season (Table 5). Herd veterinarian performing the Keto-Test, housing system, management system, average yearly production per cow and breed, and the number of DIM (7 to 21 DIM) at the time of screening were not significantly associated with ketosis (these parameters were removed from the final model shown in Table 5).

The odds of ketosis in cows that calved in the second quarter of the year (April to June) tended to be 1.3 times higher $(P=0.07)$ compared with quarter 1 [January-March; odds ratio $(\mathbf{O R})=1.3 ; P=0.07]$ and was significantly higher than quarter 3 (July-September) and 4 (October-December; OR $=1.7$ and 1.6 respectively; $P<0.01$; Table 6$)$. No significant difference was observed in odds of ketosis between cows that calved in quarter 3 and 4 . Larger lactating herd size had a small but significant association with a decreased risk of ketosis. The farms that fed PMR had a significantly higher risk of ketosis than those farms that fed a TMR $(\mathrm{OR}=1.5 ; P<0.01)$. The farms that fed forage and concentrate separately were not significantly different from those that fed a TMR and they had significantly lower odds of ketosis than those that fed a PMR (OR $=0.5 ; P<0.01)$. The odds of ketosis in parity 2 and parity 3 to 7 was significantly higher than the odds of ketosis in parity $1(\mathrm{OR}=1.5 ; \mathrm{P}=0.01$ and 2.8 and $P$ $<0.01$, respectively). The odds of ketosis in parity 8 or higher were not significantly different from parity 2 or parity 3 to 7 , but had a nonsignificant tendency to be higher than parity $1(\mathrm{OR}=1.6 ; P=0.08)$. The odds of ketosis was significantly lower in parity 2 compared with parity 3 to $7(\mathrm{OR}=0.6 ; P<0.01)$.

Diseases in study cows within $35 \mathrm{~d}$ of calving were recorded. The most common condition reported was metritis (4.8\% of cows), followed by RP (4.4\%), mastitis $(3.4 \%)$, dystocia $(2.8 \%)$, milk fever $(1.7 \%)$, clinical ketosis and lameness (1.5\%), gastrointestinal disorders

Table 3. Results of Keto-Test (Sanwa Kagaku Kenkyusho Co. Ltd., Nagoya, Japan; distributed by Elanco Animal Health, Antwerp, Belgium) screening in 131 European dairy herds and prevalence of ketosis in study cows

\begin{tabular}{|c|c|c|c|c|c|c|c|c|}
\hline \multirow[b]{2}{*}{ Item } & \multirow{2}{*}{$\begin{array}{l}\text { No. of } \\
\text { cows }\end{array}$} & \multicolumn{6}{|c|}{ Keto-Test result ( $\mu \mathrm{mol} / \mathrm{L}$ of milk) } & \multirow{2}{*}{$\begin{array}{c}\text { Ketosis } \\
\text { prevalence }^{1}(\%)\end{array}$} \\
\hline & & 0 & 50 & 100 & 200 & 500 & 1,000 & \\
\hline \multicolumn{9}{|l|}{ Country $^{2}$} \\
\hline $\mathrm{DE}$ & 910 & 277 & 255 & 233 & 101 & 40 & 4 & 42 \\
\hline FR & 578 & 132 & 161 & 162 & 83 & 33 & 7 & 49 \\
\hline IT & 930 & 361 & 272 & 167 & 86 & 35 & 9 & 32 \\
\hline NL & 1,056 & 215 & 331 & 349 & 118 & 36 & 7 & 48 \\
\hline UK & 1,235 & 500 & 359 & 291 & 73 & 10 & 2 & 30 \\
\hline Total & 4,709 & 1,485 & 1,378 & 1,202 & 461 & 154 & 29 & 39 \\
\hline Cows $(\%)$ & & 31.5 & 29.3 & 25.5 & 9.8 & 3.3 & 0.6 & \\
\hline
\end{tabular}

${ }^{1}$ Ketosis was indicated by a Keto-Test result $\geq 100 \mu \mathrm{mol}$ of BHBA/L of milk.

${ }^{2} \mathrm{DE}=$ Germany $; \mathrm{FR}=$ France; $\mathrm{IT}=$ Italy; $\mathrm{NL}=$ the Netherlands; $\mathrm{UK}=$ United Kingdom. 
Table 4. Feeding, housing, and management systems in 131 European dairy herds enrolled in a study of ketosis and the prevalence of ketosis within these systems

\begin{tabular}{llrrrr}
\hline \multirow{2}{*}{ System } & & & & \multicolumn{2}{c}{ Ketosis prevalence } \\
\cline { 5 - 6 } Feeding & Type & $\begin{array}{c}\text { Farms } \\
\text { (no.) }\end{array}$ & $\begin{array}{c}\text { Cows } \\
\text { (no.) }\end{array}$ & No. & $\%$ \\
& Forage and concentrate separate & 16 & 502 & 165 & 33 \\
\multirow{3}{*}{ Management } & 42 & 1,183 & 587 & 50 \\
& Partial mixed ration & 73 & 3,024 & 1,094 & 36 \\
& TMR & 76 & 2,966 & 1,048 & 35 \\
\multirow{3}{*}{ Housing } & Indoor all year & 52 & 1,657 & 760 & 46 \\
& Summer at pasture & 3 & 86 & 38 & 44 \\
& Outdoor alternative & 107 & 4,080 & 1,599 & 39 \\
& Cubicles & 8 & 245 & 59 & 24 \\
& Cubicles and yard & 14 & 304 & 164 & 54 \\
& Straw yard & 2 & 53 & 13 & 25 \\
\hline
\end{tabular}

(1.4\%), and DA (1.1\%; Figure 1). Separate GEE logistic models controlling for clustering of cows within farms nested within countries and controlling for parity indicated that ketosis in study cows was significantly associated with most fresh cow conditions (Table 7). The odds of the cow having had ketosis was 1.5 for metritis, 1.9 for mastitis, 3.4 for DA, 1.7 for lameness, 3.8 for gastrointestinal disorders, and 14.7 for clinical ketosis. The odds of ketosis in cows following periparturient conditions was similarly assessed through separate GEE logistic regression models (Table 8). No significantly increased odds of ketosis existed in cows following dystocia and twins. The odds of ketosis in cows that had milk fever was 2.0 and the odds of ketosis in cows following RP was 1.6. A subset of 440 cows was tested on the day of diagnosis of clinical condition occurring in the cow (Figure 2) and it indicated a high prevalence of ketosis in these cows.

\section{DISCUSSION}

This study indicates that ketosis is highly prevalent in dairy herds in Germany, France, Italy, the Netherlands, and the United Kingdom and that ketosis in postcalv- ing transition cows is associated with common disorders of fresh cows. The study was a convenience sample based upon herd enrollment performed by participating veterinary clinics spread throughout the represented countries. The herds were enrolled as typical herds of the regions, and with no routine ketosis-prevention treatments. The prevalence of ketosis reported in this study is, therefore, believed to reflect the situation in the countries. Herd-level prevalence of ketosis was lowest in the United Kingdom and Italy (31\%) and significantly higher in Germany (43\%), the Netherlands (46\%), and France (53\%). In the 5 countries, the average herd prevalence of ketosis in fresh cows 1 to 3 weeks post-calving was $41 \%$, whereas only $1.6 \%$ of the cows were diagnosed with clinical ketosis within $35 \mathrm{~d}$ postpartum. The lowest ketosis prevalence was found in Italy and this is contrary to the study by Suthar et al. (2013), where prevalence of ketosis in Italian cows was found to be significantly higher than 9 other European countries, including Germany. It is also in contrast to the higher prevalence of clinical ketosis reported in Italy compared with France, the Netherlands, and the United Kingdom in the current study.

Table 5. Generalized estimating equation (GEE) logistic regression model for ketosis in European dairy cows

\begin{tabular}{|c|c|c|c|c|c|c|c|}
\hline Parameter & Value & Code & Estimate & $\mathrm{SE}$ & $\begin{array}{l}\text { Lower } \\
\text { CI limit }\end{array}$ & $\begin{array}{c}\text { Upper } \\
\text { CI limit }\end{array}$ & $P$-value \\
\hline Intercept & Continuous & Int. & -0.826 & 0.185 & -1.188 & -0.465 & $<0.01$ \\
\hline \multirow[t]{3}{*}{ Parity } & 1 & $\mathrm{P} 1$ & 0.000 & 0.000 & 0.000 & 0.000 & Reference \\
\hline & $3-7$ & P3 & 0.742 & 0.104 & 0.539 & 0.946 & $<0.01$ \\
\hline & $8-12$ & $\mathrm{P} 4$ & 0.446 & 0.253 & -0.049 & 0.942 & 0.08 \\
\hline Calving quarter & January-March & Q1 & 0.269 & 0.187 & -0.098 & 0.636 & 0.15 \\
\hline \multirow[t]{3}{*}{ Feeding system } & Forage and concentrate separate & FCsep & -0.229 & 0.250 & -0.719 & 0.260 & 0.36 \\
\hline & Partial mixed ration & PMR & 0.422 & 0.164 & 0.099 & 0.744 & 0.01 \\
\hline & Total mixed ration & TMR & 0.000 & 0.000 & 0.000 & 0.000 & Reference \\
\hline Lactating herd size & Continuous & lactcows & -0.001 & 0.000 & -0.002 & -0.001 & $<0.01$ \\
\hline
\end{tabular}


Table 6. Odds ratios for ketosis in European dairy cows

\begin{tabular}{llccccc}
\hline Parameter & Comparison $^{1}$ & $\begin{array}{c}\text { Odds } \\
\text { ratio }\end{array}$ & SE & $\begin{array}{c}\text { Lower } \\
\text { CI limit }\end{array}$ & $\begin{array}{c}\text { Upper } \\
\text { CI limit }\end{array}$ & $P$-value \\
\hline Feeding system & FCSep vs. TMR & 0.8 & 0.2 & 0.5 & 1.3 & 0.36 \\
& PMR vs. TMR & 1.5 & 0.3 & 1.1 & 2.1 & 0.01 \\
Calving quarter & FCSep vs. PMR & 0.5 & 0.1 & 0.3 & 0.9 & 0.01 \\
& Q1 vs. Q4 & 1.3 & 0.2 & 0.9 & 1.9 & 0.15 \\
& Q2 vs. Q4 & 1.7 & 0.3 & 1.2 & 2.4 & $<0.01$ \\
& Q3 vs. Q4 & 1.1 & 0.1 & 0.8 & 1.3 & 0.61 \\
& Q1 vs. Q2 & 0.8 & 0.1 & 0.6 & 1.0 & 0.06 \\
Q1 vs. Q3 & 0.2 & 0.2 & 0.9 & 1.8 & 0.26 \\
& Q2 vs. Q3 & 1.6 & 0.3 & 1.2 & 2.2 & $<0.01$ \\
& P2 vs. P1 & 1.3 & 0.1 & 1.1 & 1.6 & 0.01 \\
& P3 vs. P1 & 2.1 & 0.2 & 1.7 & 2.6 & $<0.01$ \\
& P4 vs. P1 & 1.6 & 0.4 & 1.0 & 2.6 & 0.08 \\
& P2 vs. P4 & 0.8 & 0.2 & 0.5 & 1.4 & 0.47 \\
& P2 vs. P3 & 0.6 & 0.1 & 0.5 & 0.7 & $<0.01$ \\
& P3 vs. P4 & 1.3 & 0.3 & 0.8 & 2.2 & 0.23 \\
\hline
\end{tabular}

${ }^{1}$ FCSep $=$ forage and concentrate separate PMR $=$ partial mixed ration; $\mathrm{Q} 1$ = calving quarter 1 (JanuaryMarch); Q2 = calving quarter 2 (April-June); Q3 = calving quarter 3 (July-September); Q4 = calving quarter 4 (October-December); $\mathrm{P}=$ parity.

The diagnosis and definition of ketosis varies across studies and it is sometimes referred to as subclinical ketosis. Because we included cows that may or may not have shown clinical symptoms, we chose to simply refer to the condition as ketosis. Several studies have used BHBA serum concentrations of $1400 \mu \mathrm{mol} / \mathrm{L}$ as the suggested cutoff point to define ketosis (Radostits et al., 2000), but it may not be appropriate to set a fixed cutoff to a snapshot of the dynamic metabolic system of a transition cow. A definition of ketosis greater than $1,400 \mu \mathrm{mol}$ of BHBA/L of serum and a cutoff of $\geq 200$ $\mu \mathrm{mol} / \mathrm{L}$ of milk resulted in a sensitivity of $59 \%$ and a specificity of $90 \%$ (Geishauser et al., 2000). Krogh et al. (2011) performed a latent class evaluation of Keto-Test using $\geq 200 \mu \mathrm{mol} / \mathrm{L}$ of milk as a cutoff point for ketosis and found a high specificity of $99 \%$, but a low sensitivity of $58 \%$. For our study, the cutoff point was set at Keto-Test $\geq 100 \mu \mathrm{mol} / \mathrm{L}$ of milk for statistical analysis and this cutoff point has been estimated to correspond to $1,200 \mu \mathrm{mol} / \mathrm{L}$ of serum and give a sensitivity of $83 \%$ and a specificity of $82 \%$ (Oetzel, 2004).

Numerous factors affect the prevalence of ketosis, such as the method of detection, cutoff points, time intervals for monitoring, and parity groups monitored. Although we recognize that comparisons between studies may be biased by study methodology, it is still of interest to make some comparisons. Our study indicates that the prevalence of ketosis in these 5 European countries were in the upper range as had been reported elsewhere. In Canada, a range in herd prevalence between 0 and $34 \%$ in the first 65 DIM was reported (Dohoo and Martin, 1984). It should be noted that this was approximately $20 \mathrm{yr}$ ago and milk production has increased in this period, so it is possible that there now may be a higher prevalence of ketosis. In a study in Iran in 2011, ketosis was defined as a BHBA concentration $>1,200 \mu \mathrm{mol} / \mathrm{L}$ of serum and was detected in 63,68 , and $59 \%$, respectively, of 2-, 4-, and 6-wk postparturition tested cows (Asl et al., 2011). We did not detect any differences in the prevalence of ketosis associated with breeds as previously described (Andersson and Emanuelson, 1985) but the distribution of herds in this study provided limited power to detect significant differences in ketosis between breeds, as the vast majority of the herds were Holstein-Friesian or Holstein-Friesian mixed with other breeds. This study is, therefore, considered representa-

Table 7. Odds of ketosis in 6 separate generalized estimating equation (GEE) logistic regression models for transition cow conditions in European dairy cows

\begin{tabular}{lrccrr}
\hline $\begin{array}{l}\text { Dependent } \\
\text { factor }\end{array}$ & $\begin{array}{c}\text { Odds } \\
\text { ratio }\end{array}$ & SE & $\begin{array}{c}\text { Lower } \\
\text { CI limit }\end{array}$ & $\begin{array}{c}\text { Upper } \\
\text { CI limit }\end{array}$ & $P$-value \\
\hline Metritis & 1.5 & 0.3 & 1.0 & 2.0 & 0.03 \\
Clinical ketosis & 14.7 & 5.3 & 7.2 & 29.8 & $<0.01$ \\
Mastitis & 1.9 & 0.4 & 1.3 & 2.7 & $<0.01$ \\
Gastrointestinal disorder & 3.8 & 1.3 & 1.9 & 7.4 & $<0.01$ \\
Lameness & 1.7 & 0.5 & 1.0 & 3.1 & 0.05 \\
Displaced abomasum & 3.4 & 1.1 & 1.9 & 6.4 & $<0.01$ \\
\hline
\end{tabular}




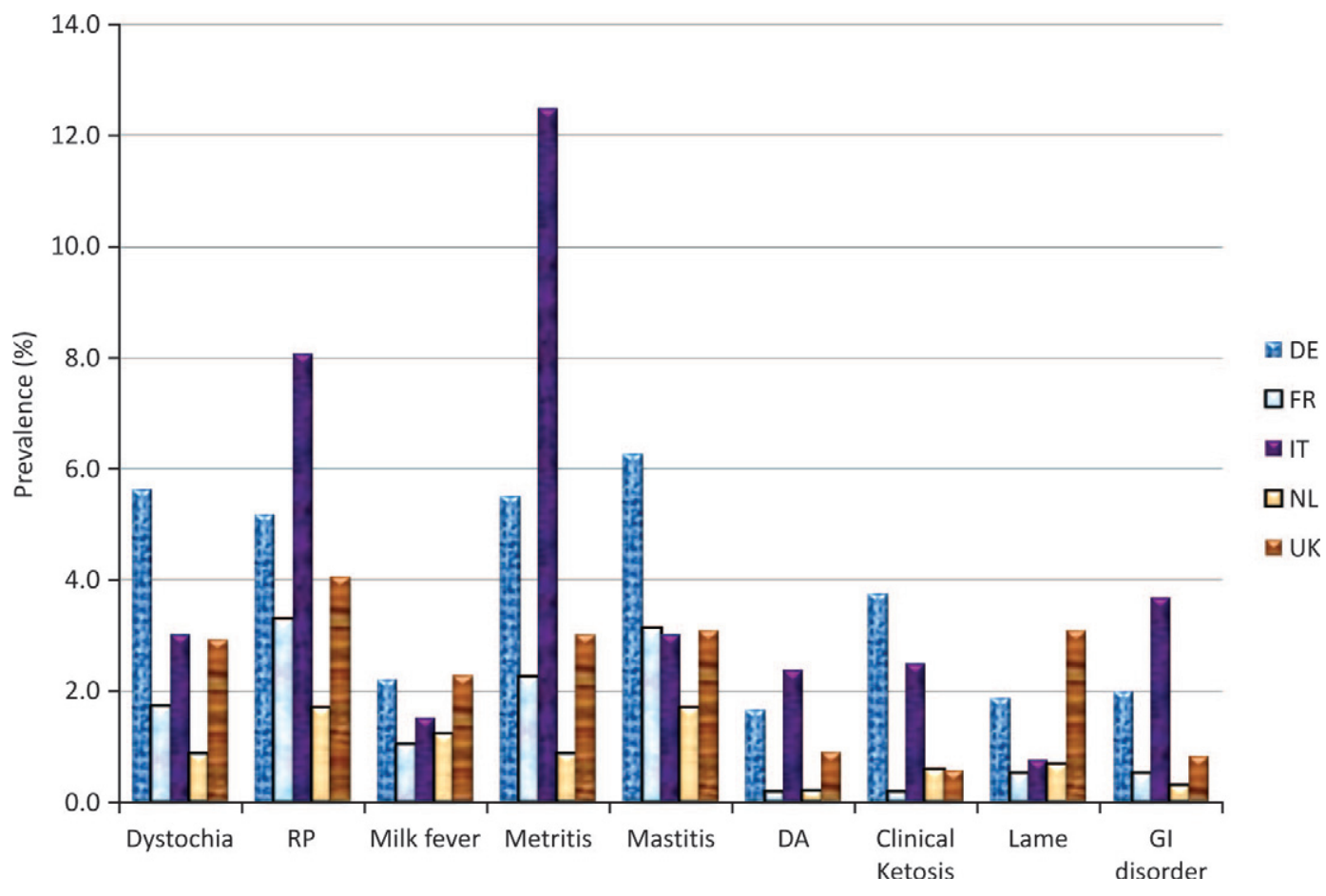

Figure 1. Prevalence of clinical fresh cow conditions in a study of ketosis in dairy cows in Europe. RP $=$ retained placenta; DA $=$ displaced abomasum; GI disorder = gastrointestinal disorder; DE = Germany; FR = France; IT = Italy; NL = the Netherlands; UK = United Kingdom Color version available in the online PDF.

tive of Holstein-Friesian herds in the 5 countries, but may not describe the situation in other breeds.

Our study indicated that a negative association existed between increases in lactating herd size and the prevalence of ketosis. A Swedish study of 40 highincidence herds for DA and clinical ketosis found that a higher maximum yield in multiparous cows and a large herd size tended to be associated with a herd being classified as a high-incidence herd for DA and clinical ketosis (Stengärde et al., 2012). The study noted that herd size was confounded with housing systems and that keeping dairy cows in only 1 group increased the risks of DA and clinical ketosis. In our study, it may be that with increases in herd size, there was more lactation stage diet specificity and a higher involvement of nutritional services. We found that levels of ketosis were lower in herds using TMR or feeding forage and concentrate separately compared with PMR. Further studies are necessary to elucidate if the different feeding approaches are causal or in other ways associated with risks of ketosis in fresh cows. The practical setup of this study with numerous clinical veterinary practices involved did not allow us to address the feeding strategy in the close-up period, or the BCS, which have previously been identified as contributing to ketosis postpartum. Several studies exist indicating a seasonal effect of ketosis and different tendencies were noted that may depend on geographical factors, such as average environmental temperature, forage quality, and access to pasture (Duffield, 2000). In our study, the highest levels of ketosis were seen in cows calving in the second quarter of the year (April-June). Quarter-2 calving events were associated with significantly higher levels of ketosis compared with quarter 3 and quarter 4 and

Table 8. Odds of ketosis in 4 separate generalized estimating equation (GEE) logistic regression models for transition cow conditions in European dairy cows following specific periparturient cow conditions

\begin{tabular}{lccccr}
\hline $\begin{array}{l}\text { Predictive } \\
\text { factor }\end{array}$ & $\begin{array}{c}\text { Odds } \\
\text { ratio }\end{array}$ & SE & $\begin{array}{c}\text { Lower } \\
\text { CI limit }\end{array}$ & $\begin{array}{c}\text { Upper } \\
\text { CI limit }\end{array}$ & $P$-value \\
\hline Retained placenta & 1.6 & 0.3 & 1.1 & 2.3 & 0.01 \\
Milk fever & 2.0 & 0.4 & 1.3 & 3.1 & $<0.01$ \\
Dystocia & 1.3 & 0.3 & 0.8 & 2.2 & 0.22 \\
Twins & 1.1 & 0.3 & 0.7 & 2.0 & 0.64 \\
\hline
\end{tabular}




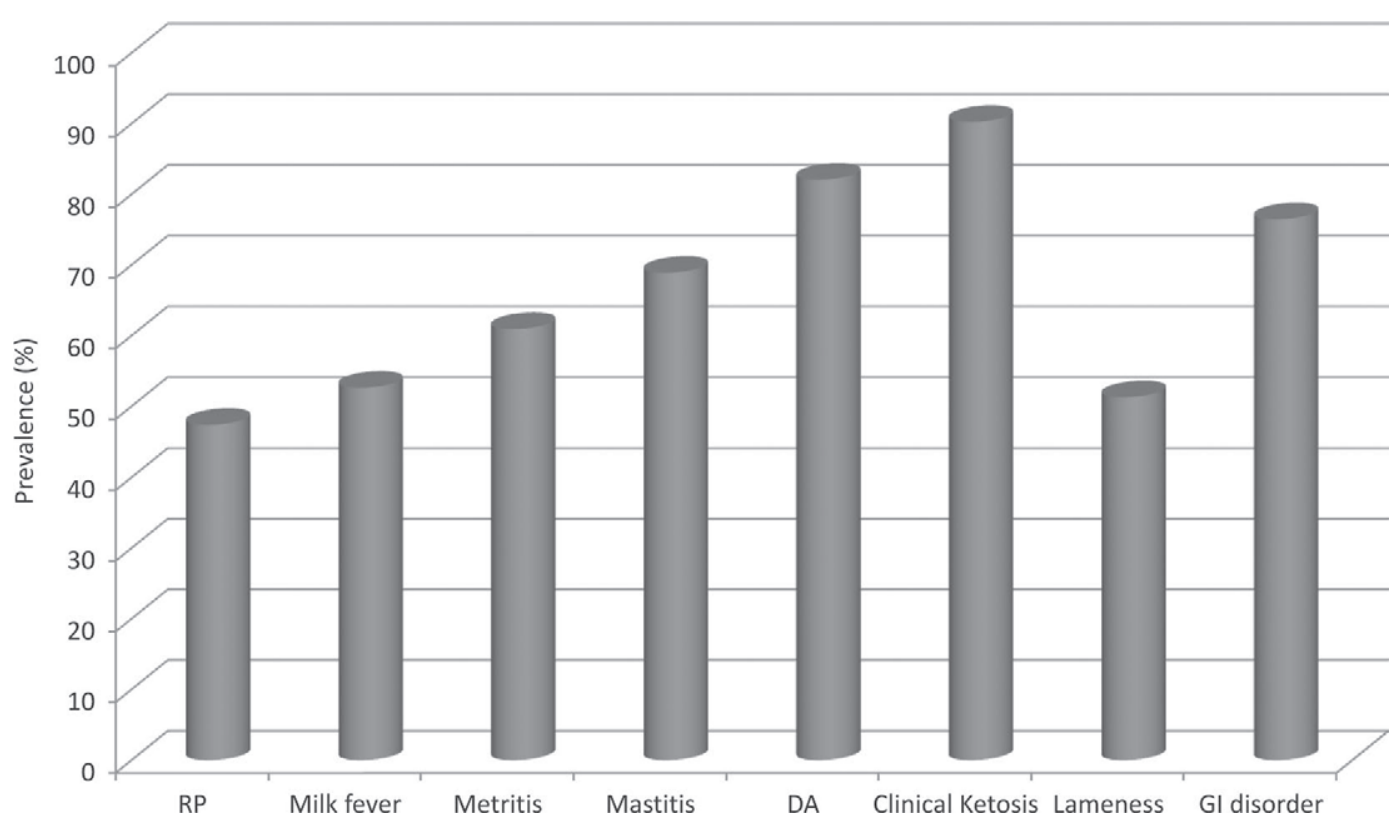

Figure 2. Prevalence of ketosis in study cows at the time of diagnosis of clinical condition. $\mathrm{RP}=$ retained placenta; DA $=$ displaced abomasum; GI disorder = gastrointestinal disorder.

tended to be higher than the first quarter. Our findings are supported by Suthar et al. (2013), who also found higher levels of ketosis in Europe in May to June 2011, compared with July to September 2011. These findings diverge from the studies that have identified the winter stabling season as the period with higher levels of ketosis (Andersson and Emanuelson, 1985; Gröhn et al., 1989) and the British study where the lowest levels of ketosis were found in May (Whitaker et al., 1983). In the past, cows may have obtained better nutrition on pasture in the spring and summer compared with the winter. However, in the current study, we found no significant association between cows being housed indoor all year compared with those that were pastured during the summers. The highest levels of ketosis in the late spring may have been due to many farmers attempting to save costs by reducing concentrates for financial reasons, starting in the spring of 2011. Less concentrates may have increased the risks for ketosis, as the cows would have consumed less energy.

The lowest prevalence of ketosis was found in cows of parity 1 , was significantly higher in cows of parity 2 , and highest in cows of parity 3 to 7 cows. Cows of parity 8 or higher were not significantly different from those of parity 2 or parity 3 to 7 with regard to prevalence of ketosis. Similarly, several studies have found that ketosis is more frequent in multiparous cows compared with primiparous cows (Carrier et al., 2004), with levels of ketosis increasing with parity (Andersson and Emanuelson, 1985; Duffield et al., 1997; Suthar et al., 2013). The transition from pregnancy to lactation represents a major challenge to homeostasis. The increase in ketosis risk in multiparous cows compared with primiparous cows may be due to gestation being concurrent with lactation and the depletion of energy reserves in multiparous cows throughout lactation. Coffey et al. (2004) have described how dairy cow body energy profiles vary both within lactation and across the first 3 lactations. In a US study of the effects of ketosis on milk yield, it was noted that loss in milk production due to ketosis varied from 3.0 to $5.3 \mathrm{~kg} / \mathrm{d}$ and that cows in parity 4 or higher were most severely affected by ketosis, where the average total loss per cow was over $300 \mathrm{~kg} /$ lactation (Rajala-Schultz et al., 1999).

Our study findings support numerous other studies indicating that ketosis in the first weeks after calving is associated with increased risks of DA, metritis, clinical ketosis, and mastitis (LeBlanc, 2010). Due to missing records regarding the dates of disease on several farms, our study did not allow us to determine the temporal relationships between disease diagnosis and study screening. Because our investigation measured ketosis at a single time point and ketosis has been shown to last up to several weeks (Asl et al., 2011), the temporal relationships are difficult to evaluate in this type of field study. As ketosis is one part of a metabolic syndrome that occurs in transition cows, it follows that one event may not precede the other but all are part of homeorhetic changes occurring at this stage. A study with 2,365 cows in 55 herds in Canada and the United 
States that evaluated BHBA, NEFA, and calcium concentrations pre- and postpartum showed that elevated serum NEFA concentrations within 1 wk before calving were associated with increased risks of RP, metritis, and DA after calving, whereas the association between serum BHBA and RP was not significant (Chapinal et al., 2011). In a prospective cohort study of 100 freestall, TMR-fed herds in the northeastern United States, all risk ratios with serum BHBA concentration (>10 mg/ $\mathrm{dL})$ as the predictor of DA, clinical ketosis, metritis, and RP within 30 DIM were greater than 2.3 (Ospina et al., 2010b).

We found that cows that had been diagnosed with ketosis were almost twice as likely to have a mastitis event diagnosed in the first $35 \mathrm{~d}$ of lactation. Previous studies have also found that clinical ketosis is associated with a 2-fold increase in the risk of clinical mastitis (Oltenacu and Ekesbo, 1994). In a Canadian study, 28.6\% of cows with prepartum ketosis subsequently developed clinical mastitis compared with $8.7 \%$ of cows without prepartum ketosis (Leslie et al. 2000). An increased incidence of clinical mastitis in high-producing cows has been reviewed and it was concluded that it could be due to the impairment of udder defense mechanisms during hyperketonemia (Suriyasathaporn et al., 2000). However, Suthar et al. (2013) failed to detect an association between mastitis and ketosis.

We noted a significant association between ketosis and reported clinical lameness. An observational study in Wisconsin found that lameness significantly altered the resting behavior of cows during the transition period and was associated with elevated risk of ketosis in a mattress-bedded commercial freestall facility (Calderon and Cook, 2011). Suthar et al. (2013) reported a 3.2\% prevalence of lameness in the 10 European countries studied and similarly found associations between lameness and ketosis.

\section{CONCLUSIONS}

This field study of European dairy herds in the United Kingdom, France, Germany, Italy, and the Netherlands, indicates that ketosis is highly prevalent in fresh cows and is associated with common postpartum diseases, including metritis, mastitis, milk fever, lameness, gastrointestinal disorders, clinical ketosis, and DA. The strong associations between ketosis and disease indicates that interventions to improve nutrition and management that decrease ketosis will likely result in a reduction of production diseases. The milk Keto-Test proved to be a noninvasive and user-friendly method to assess herd ketosis prevalence. Further studies are necessary to find discover management and feeding systems that can reduce herd prevalence of ketosis.

\section{ACKNOWLEDGMENTS}

We are grateful to all veterinarians and farmers participating in this study and Elanco Animal Health (Antwerp, Belgium) for financial and scientific support.

\section{REFERENCES}

Agresti, A. 2002a. Analyzing repeated categorical response data. Pages 455-490 in Categorical Data Analysis. John Wiley \& Sons Inc., New York, NY.

Agresti, A. 2002b. Multinomial response models. Pages 267-302 in Categorical Data Analysis. John Wiley \& Sons Inc., New York, NY.

Andersson, L. 1988. Subclinical ketosis in dairy cows. Vet. Clin. North Am. Food Anim. Pract. 4:233-251.

Andersson, L., and U. Emanuelson. 1985. An epidemiological study of hyperketonaemia in Swedish dairy cows; determinants and the relation to fertility. Prev. Vet. Med. 3:449-462.

Asl, A. N., S. Nazifi, A. R. Ghasrodashti, and A. Olyaee. 2011. Prevalence of subclinical ketosis in dairy cattle in the Southwestern Iran and detection of cutoff point for NEFA and glucose concentrations for diagnosis of subclinical ketosis. Prev. Vet. Med. 100:38-43.

Baird, G. D. 1982. Primary ketosis in the high-producing dairy cow: Clinical and subclinical disorders, treatment, prevention, and outlook. J. Dairy Sci. 65:1-10.

Calderon, D. F., and N. B. Cook. 2011. The effect of lameness on the resting behavior and metabolic status of dairy cattle during the transition period in a freestall-housed dairy herd. J. Dairy Sci. 94:2883-2894.

Carrier, J., S. Stewart, S. Godden, J. Fetrow, and P. Rapnicki. 2004. Evaluation and use of three cowside tests for detection of subclinical ketosis in early postpartum cows. J. Dairy Sci. 87:3725-3735.

Chapinal, N., M. Carson, T. F. Duffield, M. Capel, S. Godden, M. Overton, J. E. Santos, and S. J. LeBlanc. 2011. The association of serum metabolites with clinical disease during the transition period. J. Dairy Sci. 94:4897-4903.

Chapinal, N., M. E. Carson, S. J. LeBlanc, K. E. Leslie, S. Godden, M. Capel, J. E. Santos, M. W. Overton, and T. F. Duffield. 2012. The association of serum metabolites in the transition period with milk production and early-lactation reproductive performance. J. Dairy Sci. 95:1301-1309.

Coffey, M. P., G. Simm, J. D. Oldham, W. G. Hill, and S. Brotherstone. 2004. Genotype and diet effect on energy balance in the first three lactations of dairy cows. J. Dairy Sci. 87:4318-4326.

Dohoo, I. R., and S. W. Martin. 1984. Subclinical ketosis: Prevalence and associations with production and disease. Can. J. Comp. Med. 48:1-5.

Dubuc, J., T. F. Duffield, K. E. Leslie, J. S. Walton, and S. J. LeBlanc. 2012. Risk factors and effects of postpartum anovulation in dairy cows. J. Dairy Sci. 95:1845-1854.

Duffield, T. 2000. Subclinical ketosis in lactating dairy cattle. Vet. Clin. North Am. Food Anim. Pract. 16:231-253,v.

Duffield, T. F., D. F. Kelton, K. E. Leslie, K. D. Lissemore, and J. H. Lumsden. 1997. Use of test day milk fat and milk protein to detect subclinical ketosis in dairy cattle in Ontario. Can. Vet. J. 38:713-718

Geishauser, T., K. Leslie, D. Kelton, and T. Duffield. 1998. Evaluation of five cowside tests for use with milk to detect subclinical ketosis in dairy cows. J. Dairy Sci. 81:438-443.

Geishauser, T., K. Leslie, J. Tenhag, and A. Bashiri. 2000. Evaluation of eight cow-side ketone tests in milk for detection of subclinical ketosis in dairy cows. J. Dairy Sci. 83:296-299.

Gröhn, Y. T., H. N. Erb, C. E. McCulloch, and H. S. Saloniemi. 1989. Epidemiology of metabolic disorders in dairy cattle: Association among host characteristics, disease, and production. J. Dairy Sci. 72:1876-1885.

Holmes, J. R. 1950. Observations on the incidence of subclinical ketosis in a dairy herd. Br. Vet. J. 106:365-377. 
Krogh, M. A., N. Toft, and C. Enevoldsen. 2011. Latent class evaluation of a milk test, a urine test, and the fat-to-protein percentage ratio in milk to diagnose ketosis in dairy cows. J. Dairy Sci. 94:2360-2367.

LeBlanc, S. 2010. Monitoring metabolic health of dairy cattle in the transition period. J. Reprod. Dev. 56(Suppl.):S29-S35.

Leslie, K. E., T. F. Duffield, and Y. H. Schukken. 2000. The influence of negative energy balance on udder health. Pages 25-33 in Proc. National Mastitis Council Regional Meeting. National Mastitis Council, Verona, WI.

McKay, S. 2012. Subclinical ketosis: Frequent and an expensive problem. Tijdschr. Diergeneeskd. 137:686-687,689. (Article in Dutch).

McLaren, C. J., K. D. Lissemore, T. F. Duffield, K. E. Leslie, D. F Kelton, and B. Grexton. 2006. The relationship between herd level disease incidence and a return over feed index in Ontario dairy herds. Can. Vet. J. 47:767-773.

Oetzel, G. R. 2003. Herd-based biological testing for metabolic disorders. Adv. Dairy Technol. 15:275-285.

Oetzel, G. R. 2004. Monitoring and testing dairy herds for metabolic disease. Vet. Clin. North Am. Food Anim. Pract. 20:651-674.

Oltenacu, P. A., and I. Ekesbo. 1994. Epidemiological study of clinical mastitis in dairy cattle. Vet. Res. 25:208-212.

Ospina, P. A., D. V. Nydam, T. Stokol, and T. R. Overton. 2010a. Associations of elevated nonesterified fatty acids and $\beta$-hydroxybutyrate concentrations with early lactation reproductive performance and milk production in transition dairy cattle in the northeastern United States. J. Dairy Sci. 93:1596-1603.

Ospina, P. A., D. V. Nydam, T. Stokol, and T. R. Overton. 2010b. Evaluation of nonesterified fatty acids and $\beta$-hydroxybutyrate in transition dairy cattle in the northeastern United States: Criti- cal thresholds for prediction of clinical diseases. J. Dairy Sci. 93:546-554

Radostits, O. M., C. C. Gay, D. C. Blood, and K. W. Hinchcliff. 2000. Ketosis in ruminants. Pages 1452-1456 in Veterinary Medicine: A textbook of the Diseases of Cattle, Sheep, Pigs, Goats and Horses. O. M. Radostits, C. C. Gay, D. C. Blood, and K. W. Hinchcliff, ed. Harcourt Publishers Ltd., London, UK.

Rajala-Schultz, P. J., Y. T. Grohn, and C. E. McCulloch. 1999. Effects of milk fever, ketosis, and lameness on milk yield in dairy cows. J. Dairy Sci. 82:288-294.

Roberts, T., N. Chapinal, S. J. LeBlanc, D. F. Kelton, J. Dubuc, and T. F. Duffield. 2012. Metabolic parameters in transition cows as indicators for early-lactation culling risk. J. Dairy Sci. 95:30573063.

Stengärde, L., J. Hultgren, M. Tråvén, K. Holtenius, and U. Emanuelson. 2012. Risk factors for displaced abomasum or ketosis in Swedish dairy herds. Prev. Vet. Med. 103:280-286.

Suriyasathaporn, W., C. Heuer, E. N. Noordhuizen-Stassen, and Y. H. Schukken. 2000. Hyperketonemia and the impairment of udder defense: A review. Vet. Res. 31:397-412.

Suthar, V. S., J. Canelas-Raposo, A. Deniz, and W. Heuwieser. 2013. Prevalence of subclinical ketosis and relationships with postpartum diseases in European dairy cows. J. Dairy Sci. 96:2925-2938. http://dx.doi.org/10.3168/jds.2012-6035.

Whitaker, D. A., J. M. Kelly, and E. J. Smith. 1983. Subclinical ketosis and serum beta-hydroxybutyrate levels in dairy cattle. Br. Vet. J. 139:462-463. 